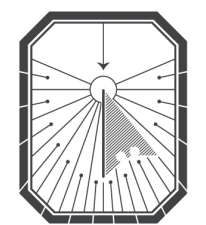

KYIV-MOHYLA

LAW \& POLITICS JOURNAL

KYIV-MOHYLA SCHOLARLY PEER-REVIEWED JOURNALS

Legal Interpretation in Post-truth Society: Ukrainian Case

Author(s): Ievgen Zvieriev

Source: Kyiv-Mohyla Law and Politics Journal 4 (2018): 81-98

Published by: National University of Kyiv-Mohyla Academy

http://kmlpj.ukma.edu.ua/ 


\title{
Legal Interpretation in Post-truth Society: Ukrainian Case ${ }^{1}$
}

\author{
Ievgen Zvieriev \\ National University of Kyiv-Mohyla Academy, \\ Department of Legal Philosophy and Constitutional Law
}

\begin{abstract}
Since Euromaidan and the beginning of annexation of Crimea and hostilities in the East of Ukraine post-truth was not much in focus of Ukrainian scholars. The events mentioned above have pulled the trigger of interest to the term in international scholarly world. Ukraine was not an exception in this situation. Having suffered through the consequences of post-truth practical application, Ukrainians have much to say on the matter of post-truth description and on the matter of dealing with it. My specific interest concerned the area of law, and this article focuses on the role post-truth plays in legal fields. I go over the basic ideas of post-truth, analyze its origin and influence, as well as provide examples of its legal application in Ukrainian environment.
\end{abstract}

Key Words: post-truth, legal interpretation, Ukraine, students, municipal officials.

\section{Introduction}

"Post-truth" was selected the word of year in 2016 by Oxford Dictionaries, but its significance in the reality of today's world has not diminished. ${ }^{2}$ It has been included in other dictionaries and in textbooks and manuals. Many commentators, academic and otherwise, have addressed and continue to address post-truth in their numerous works in philosophy, linguistics, religion, culture, and law. Post-truth remains a major focus of the media. Some have analyzed it; reported about it; or applied it, all for reasons spread across many different aspects of our modern reality.

1 The Author would like to express his thanks to Folke Bernadotte Academy for providing possibility to fruitfully participate in "Local Self-Government and Rule of Law in Ukraine" project which provided rich intellectual grounds for this article. Additionally the author wishes to thank his numerous students whose participation in his teaching activities has also significantly contributed to this piece. Additional words of appreciation go to Professor Mykola Koziubra for grounded critical remarks and to Professor Christopher Kelley for wonderful English review."

"Word of the Year 2016 is Post-Truth," accessed December 16, 2018, https://en.oxforddictionaries. com/word-of-the-year/word-of-the-year-2016. 
"Post-truth" may be a new adjective, but had it existed as an adjective since ancient times it could have characterized many occasions when facts were shaded, glossed over, or denied in favor appeals to others' emotions ${ }^{3}$ instead of appeals to reason. Indeed, this might have happened soon after the second person on Earth was created. The first person undoubtedly had incentives to influence the second one. And this influence might have been through means that avoided or misstated the truth. Thus, the idea of post-truth might not be fertile ground for new discoveries. Nevertheless, it cannot be denied that trafficking in falsehoods has had and continues to have a significant impact on today's reality around the world.

This article's aim is not to discover or elaborate on the philosophical grounds of the post-truth phenomenon. I will leave this to the philosophers and will not delve deeply into the concepts of perception, understanding, and the like. Nor will I delve deeply into the linguistic or psychological foundations and attributes of post-truth. My aim instead is to discover the affects post-truth may impose on the law and legal reality through legal interpretation.

I start with providing a definition of post-truth as I see it for my purposes here. I then elaborate on the issue of legal interpretation as an instrument in which posttruth characterizes the method applied. In this regard, I focus on the interpretation of the concept of law by providing the results of my students' ideas as they revealed them in my classes, analyze the possible post-truth impact of their interpretation of law and also provide the results of my experiment with municipal officials of selected Ukrainian cities and local NGO leaders and members who operate in the same Ukrainian cities. I conclude with an analysis of the state of legal interpretation in Ukraine using as an illustrative example a significant Ukrainian Constitutional Court case in which applying a simple post-truth mechanism significantly turned Ukrainian history. This example related to events that mainly took part in 2014 yet continue today.

\section{Post-truth}

I do not consider post-truth to be newly invented. ${ }^{4}$ Techniques for manipulating people's thinking have a long history; human societies have always used them. History has recorded religious, psychological, cultural, and many other forms of manipulation

3 Oxford dictionaries provide the following definition of post-truth: "Relating to or denoting circumstances in which objective facts are less influential in shaping public opinion than appeals to emotion and personal belief," Oxford Dictionaries, accessed December 16, 2018, https://en.oxforddictionaries.com/definition/post-truth. The idea of influencing someone else does not seem to be new, while the appeal to emotions as a primary, and not auxiliary means to reach that goal being proved by practice did most probably influence the selectors who have chosen it a word of the year.

This is a very popular approach expressed in many sources, for example in this blog, accessed May 15, 2018, https://posttrutherablog.com/2017/02/27/what-is-post-truth/. 
whose bounds were limited only by the limits of the human imagination and credulity. What is new is that these techniques were not called post-truth before.

Post-truth appears to me as a modernized form of the manipulation of the concept of truth and significant (or primary) recourse to people's emotions. That this term was not widely used before ${ }^{5}$ is mostly due to the strong belief most members of the modern civilized world had that we currently live in a modern era, and all the mistakes humanity has made before, all the drawbacks humanity has had in the past, will not be repeated. This approach is easily noticeable in the text and spirit of the United Nations Charter, different significant human rights conventions and declarations, state constitutions, laws, and even company charters. I must admit that I once adhered to the same view. I had strongly believed that wars are over and would never be repeated as humanity should have learnt something from the ones it has already fought. Thus, it seems to me that I was a victim of post-truth myself, at least if we consider that aspect only. I had a strong idea. I believed it. I thought I had facts to support my belief, and I also had a strong emotional feeling about it.

This state is called an "information bubble" by different scholars, and I cannot agree more to the definiteness of this term. ${ }^{6}$ I was completely within the boundaries of my own perceptions of true and false and of right and wrong. Moreover, I had support as many other people who surrounded me shared my ideas, thus belonging with me in this "information bubble." All this has clear characteristics of post-truth within the definition of the Oxford Dictionaries. Therefore, I must admit that the amount of people in the world being found within this information bubble was quite significant.

These bubbles still exist in different parts of the world on different issues, and I acknowledge that I am still within quite a few of them, as are also many other people whether they realize it or not. This means that post-truth still has many instruments to affect us and our decisions. Moreover, this means that we need to realize all the benefits and dangers it may bring, and be ready for the consequences.

I wish to also further elaborate on the effects of post-truth. This term is usually being perceived as a term with a negative condition. This is true in many cases, but it is not true in all of them. Quite often we appeal to someone else's emotions to achieve something positive, to provide positive effects for someone, to influence someone in a positive way. We do that when we show anti-tobacco posters to our kids who have started smoking, we do that by playing sports with them, by involving them in our day-to-day activities, sharing our experiences in applying whatever skills we may have. In most cases we do wish to manipulate our kids, and to teach them some good and

In fact, this term was not invented recently. Most sources attribute the first usage to SerbianAmerican playwright Steve Tesich in 1992, Oxford Dictionaries, accessed May 15, 2018, https:// www.oxforddictionaries.com/press/news/2016/12/11/WOTY-16.

6 See e. g. Egor Konev, "Zhurnalistskie printsipy v epohu postpravdy [Journalist Principles in Post-truth Era]," in Mezhdunarodnaya zhurnalistika 2018. Globalnye vyzovy, regionalnoe partnerstvo i media. Materialy VII Mezhdunarodnoi nauchno-prakticheskoi konferentsii (Minsk, 2018), 140. 
useful life values or life skills. In many of these circumstances we also appeal to our kids' emotions. This falls completely within post-truth's Oxford definition.

Nevertheless, it is not that often that applying post-truth techniques under such conditions will lead to some harm for our kids. Drinking alcohol occasionally has very high chances to be picked up by our children, as is smoking, regardless of the amount of anti-tobacco and anti-alcohol posters we show them.

However, the dangers of post-truth are that it is a very adaptable and multifunctional mechanism, and thus it can easily be converted from achieving something positive to quite the opposite.

\section{Post-truth in Law}

Law is one of the disciplines most vulnerable to post-truth effects. Because the law relies heavily on facts, post-truth may pose a significant risk to the very essence of law, on how others understand it, and most importantly, on how the law should be applied. ${ }^{7}$ I would also call post-truth an instrument of the law, as it surrounds the law and legal reality and exists within them and with them. Most cases before a court are in fact the competition of different versions of post-truth being presented by the parties and/or by their lawyers. Regardless of whether we follow the common law tradition or civil law tradition, the idea of creating the reality which most follows the interests of the party is not new in legal practice. In fact, ideally the law must be concerned with finding truth, resolving conflicts basing on important principles of justice, equality, judicial independence, and many other principles. In fact, though, the lawyers usually view truth not as a goal they are supposed to achieve (by discovering it) but in most cases what lawyers call "truth" is simply the state when the other party is not able to prove that your position is wrong. This is quite far from philosophic perception of truth, however.

This is now a matter of value. It is a matter of the value of each party's truth that can be, and usually is, measured by the court or the arbitration tribunal. But is truth that is being measured during court/arbitration hearings? Should we not regard truth as something absolute, something static, something unchangeable at least under certain set conditions? I will leave that one to philosophers as the issue has become more of their concern. My personal view is that in the cases described, we are not dealing with the truth. We are dealing with post-truth that competes with another post-truth aiming to achieve the goals of each party. The truth is usually hiding between them and is not that easy to discover. That way, post-truth is a powerful instrument in lawyers' (and parties') hands that permits them to achieve their goals in court/arbitration hearings as well as in other settings where there is a competition of facts presented by certain parties.

7 See more on truth in law in Andrei Marmor, "Truth in Law" USC Legal Studies Research Paper 11.3 (2011): 1-28 and numerous other sources. 
This is a very simple analysis, however. I think that in addressing the issue of posttruth in law we need to further elaborate on the nature of law, on what the law really is. That is a very difficult question. Modern scholarship includes billions of definitions of law, and not one of these definitions (once pronounced by some of us) is fully accepted by everyone else. ${ }^{8}$ This poses more fertile ground for post-truth to be applied. This is how the world ended up with Civil Law, Common Law, Islamic Law, and Socialist Law (as well as other less common families of law). Many other examples can be added to this incomprehensive list.

I do not wish to elaborate on the definition of law in this article either. There are numerous works addressing this issue. ${ }^{9}$ I wish to focus on analyzing the effects posttruth may have on law and their potential consequences.

The definition of law may also be subject to post-truth influence as the definition accepted by most of the actors in the legal field has changed with time. Even having no widely accepted definition of law, it is hard not to admit that the law within an empire is not the same as the law within a republic. It is hard not to admit that the law in democratic state has a different meaning than the law in a dictatorship. This list of examples could continue. And here comes the major issue of this part of the research. This issue is whether this change is determined or at least influenced by post-truth. Let's elaborate on that for a while.

I decided to make a survey this year. Having taught three different courses to the students at my university, I decided to find out what they think the law is. I've taught 125 first-year students in a Bachelor of Laws History of Legal Thought course. I've also taught 78 fifth-year students in the Master of Laws Theory of Lawmaking course, and I've also taught 40 third-year students in a Bachelor of Political Science Comparative Constitutional Law course. All of these students received an assignment to draw their image of law and support it with law's definition. This was a task to complete at home, and all of them could use any possible means to perform it. But they had to reveal their own understanding of the concept. All of them completed this assignment and brought their drawings to class.

It was interesting for me to see what my students think. By knowing how they think, I can understand what to do with them, what teaching approach I should apply, and what topics I should specifically focus on as their instructor. The assignment has also provided me with valuable teaching material that was used later in the classroom for pedagogic purposes. My other aim was also to analyze how the definition of law would differ among younger and older law students and how the perception of law by law students would differ from the perception of law by political science students. The results were quite unexpected for me.

I received many different approaches in their drawings, written definitions, and oral explanations the students had a chance to provide. Their drawings differed in size,

8 This conclusion is made in numerous sources, the recent one being: Mykola Koziubra, Zahalna teoriya prava [General Theory of Law] (Kyiv: Vaite, 2015), 40-43. 
preciseness, by author's drawing talent (some would deserve a place in the exhibition hall), color, technique, and many other features. I received almost all possible types of art I could get. This also was true of their definitions of law (both oral and written). Some used an academic approach, others relied on metaphor. One of the students wrote a poem while defining law. There was a very broad range of definitions starting with the traditional approach most common for Ukrainian society and ending with different exotic drawings and definitions. However, what impressed me was the fact that quite a few definitions and drawings provided by first-year students resembled the natural law theory approach to defining law instead of the Soviet positivist legal perception they were taught in high school. Many of their pictures resembled different aspects of human rights, nature (trees, grass, rivers, sea, and blue sky that resembled natural state as they explained it), and quite a few definitions referred to law as possibilities and not as legal rules as positivists mostly understand the law. Quite a few of them drew scales as the symbol of law (which wasn't unexpected). Only a handful of first-year students drew something that resembled force.

The small number of images that resemble force were quite unexpected as most people in Ukraine still follow the old Soviet approach and view the law as something that appears in the uniform of a police inspector with certain charges to be applied for a certain violation. During the Soviet era, courts were viewed and still are viewed by many people as bodies whose primarily goal is to punish people for wrongdoings. The idea that the court's primary goal is not serving as a punishing body but as a body serving justice was almost non-existent in former Soviet Union and is still almost nonexistent in Ukraine's elderly population's thinking. All this does in fact resemble posttruth influence.

I was very much surprised by the outcome I received from the older law students. Most of them already have part-time jobs, and quite a few are already engaged in legal practice as paralegals mostly. They combine their jobs with studies, and due to the harsh economic conditions Ukraine is in right now, we tolerate this to the extent it does not influence their performance in class. These students have mostly revealed a very positivist approach to law, naming it a set of established rules which all the members of the society must follow. Their drawings, however, were not as dogmatic. Many revealed the image of scales with different elements (supplying them with positivist definitions, however). They explained orally that this is how they see justice. There were some who turned their attention to human rights. One drawing expressly stated that the law must include minimum of the moral values.

The political science students mostly provided stereotypic drawings and textbook definitions of law, while many of them stated that law is mostly a mechanism that is applied to achieve certain goals. Most strangely, one of the students who provided this definition had submitted a clear sheet of paper as his drawing, explaining orally that anything can be built on the clear sheet of paper that the law provides.

As for me, all the three experiments showed the clear influence of post-truth on the perception of law by my students. Each group is living within their own information bubble, whether these are first-year law students or fifth-year law students or third-year 
political science students. This bubble is determined by their age, experience, and their background. The bubble is also very much influenced by their goals. It is no wonder that political science students mostly did not write their own definitions of law and relied mostly on the ones they found in different textbooks. They did not deal much with legal issues, and it was quite difficult for them to express their understanding of something they did not fully understand at that time. It is also quite natural that the ones who did not use a textbook definition would view law as a tool, was an approach not uncommon among political scientists. I expected all this.

I also see clear signs of post-truth influence here. Their ideas were within their group, which shared common values. The definition of law appealed to their emotions as it has much to do with personal feelings. They got the inverted facts that seemed true but did not reveal the full truth (the case with viewing law as a tool, for example).

I plan to repeat this experiment next year, but the results I received have already provided valuable data for analysis. I will further focus on these results in this article after I point out another important aspect of this article's focus. Let's turn to legal interpretation.

\section{Legal Interpretation}

I usually start my Legal Interpretation course with the phrase: "Interpretation of interpretation is itself an interpretation." It is as true and as confusing as it may be. Defining "legal interpretation" has never been an easy task. Some would call it a process of extracting truth or substance or meaning out of something (the object of the interpretation). ${ }^{10}$ Some adherents to this approach would also substitute construction with interpretation, and would define it as a process of ascribing meaning to something. ${ }^{11}$ There are also views that interpretation is merely a result of the process. ${ }^{12}$ The majority of scholars would combine the two approaches.

Interpretation has always been one of the vital skills for lawyers. It gives them the possibility to master their work and to be able to defend a client or to make a just decision or to provide a just sentence. It has always been a powerful tool. No wonder that there were times in human history that legal interpretation became completely forbidden by the ruling emperors or other representatives of the state power in different nations (Justinian in Byzantine Empire, Medieval Austria, Medieval Prussia). ${ }^{13}$

10 Vladik S. Nersesyanc, Obshchaya teoriya prava i gosudarstva [General Theory of Law and State] (Moscow: Norma, 2002), 491.

11 Arthur Schiller, "Roman Interpretatio and Anglo-American Interpretation and Construction," Virginia Law Review 27.6 (1941): 734-35.

12 Michael Moore, "Interpreting Interpretation," in Law and Interpretation. Essays in Legal Philosophy, ed. Andrei Marmor (Oxford: Clarendon Press, 1997), 6.

13 Shugrina, Elena, Tekhnika yuridicheskogo pisma [Technique of Legal Drafting] (Moscow: Delo, 2000), 61; Ian Maclean, Interpretation and Meaning in the Renaissance: The Case of Law (Cambridge; New York: Cambridge University Press, 1992), 50-59. 
Interpretation's uniqueness as one of the legal tools is that it is like a knife. It can both save lives and kill people. It can both do serious harm and provide important relief. That is why it is vitally important for students to understand how to apply different interpretative techniques and to know these techniques' limits. This is not an easy task for experienced lawyers. It is way more difficult for the students who do not have much life experience and often may be subject to different vulnerabilities.

The importance of legal interpretation for this research is that it is a primary tool for post-truth in law. Different combinations of legal interpretation methods are widely applied by all those interested in establishing a post-truth "information bubble" that would help them achieve their legal goals.

The results of my experiment with students' law definitions revealed some considerations. Most of the students (99\% of them in all the three classes I had taught) were not born in Soviet Union but were born and raised in times of change when old Soviet approaches were slowly replaced by the new ones. The paradox is that I expected to get more positivist definitions of law from the first-year students who were mostly taught by Soviet-trained teachers using textbooks that resemble an old Soviet positivist approach to the law; that is, a set of established rules imposed by the state. I did my own research on the issue, and it revealed that these high school textbooks still operate with this definition. Nevertheless, the younger first-year students who have just started their university path to a law diploma mostly perceive law as a set of possibilities, not as a set of rules. They proved it in writing and orally and through their drawings.

I have two explanations for this. First, they are still young and full of maximalist ideas. This audience would consider the idea of law as a possibility appealing, as it is a worldwide trend for the students who have just left the school to be fed up with all sorts of rules and start looking for something else to associate their understanding of the law with.

Second, these students did not experience the totalitarian regulatory apparatus of the Soviet state that affected almost all aspects of the lives of Soviet citizens. Regardless of what they found in high school law textbooks, first-year students had already been raised in the newly independent Ukraine that provided many more possibilities and freedoms than was the country I was born in (Soviet Union). I could consider these more recent times to be when post-truth failed and the information bubble that was carefully formed for over 70 years of Soviet rule burst, thus allowing these young students to find themselves in another dimension that gives them possibility to choose and not to simply follow. However, this dimension is formed by another information bubble that has replaced the old one. All this is still subject to those who have applied post-truth techniques before and continue to apply them by targeting primarily the young people's emotions. They still favor an idealistic approach to the understanding of the law.

I also did not expect the results I have got from the older law students. Given the fact that almost all the professors of my university (and though it is my alma mater, I can prove it from my own experience as a former student) are adherents of natural 
law theory, I expected to get the appropriate definitions. It was mostly the opposite, however. I have asked myself and asked my students why, and we all agreed that this is the legal practice that most of these students were already engaged in and this formed their view opposite to my expectations.

It is hard to admit, but we need to realize that the years of positivist domination in the legal sphere of Soviet Ukraine still bring their fruits. Most people who make legal decisions in Ukraine were trained in Soviet times, adhere to those values, and cannot simply change because times and the country have changed.

In the past two years, I have observed that my department is heavily engaged in various projects, one of them being "Local Self-Government and Rule of Law in Ukraine" being conducted jointly by the Swedish Folke Bernadotte Academy and the National University of Kyiv-Mohyla Academy and carried out by my department. ${ }^{14}$ The idea of the project is to distinguish 12 partner cities of different size and in different regions of the country and to promote rule of law values in these 12 selected municipalities. To achieve this, the project hired a sociological agency that made its own research in each city regarding the level of the acquaintance of local people with rule of law values. They focused on three groups of respondents: municipal officials, local NGO leaders and members, and ordinary people who appeared to be in the municipality building at a certain day and time. Upon the completion of these studies, I and my colleagues held a set of seminars for municipal officials and for local NGO leaders and representatives in each city, where we shared our academic knowledge on what rule of law is, how it functions, and how they could apply it in their day-to-day activities. While doing this, we made our own questionnaires that we offered to the participants to complete. They did this before the training and after the completion of the program. We have also had lively chats with people on different points, so I think we had a chance to get the impression on what the ideas of our audience were.

I must say that I was not surprised to find out that most (around 99\%) of the municipal officials (who may or may not have had legal education) view rule of law as a set of nice words not really meaning anything exact, not applicable to anything, and having as their only purpose to be inserted into different documents to fulfill the current political trend. I was very much surprised that a smaller percentage, but still majority (around 6o\%), of NGO members expressed the same idea. It was surprisingly strange that we received these results regardless of the region where we held our trainings. The results were similar in Eastern (traditionally pro-Russian and mostly Russian-speaking) cities and Western (traditionally anti-Russian and mostly Ukrainian-speaking) cities.

Same applies to their perception of law which was revealed during trainings and conversations with both groups of participants. Law is (in their view) a mere set of rules and regulations that aim mostly to forbid someone from doing something or to punish someone for something done wrongly. I was very much surprised to get that

14 Folke Bernadotte Academy, "Local Self-Government and Rule of Law in Ukraine," accessed December 7, 2018, https://fba.se/en/how-we-work/rule-of-law/local-self-government-and-ruleof-law-in-ukraine/. 
kind of a response from the members of different NGOs. In private conversations they told us that their perception of rule of law concept and of the concept of law itself had changed due to their practical experience. One of the NGO leaders (who preferred not to reveal his/her name) said the following: "The legal system did not give us a chance to feel the real essence of the rule of law, thus it should mean that what we thought rule of law is was wrong, and it is in fact what the municipal and state officials think it is."

This example resembles a clear post-truth influence on minds that supposedly should have adhered to another position. Nevertheless, their practical experience had provided the boundaries of information bubble they lived and worked in. This bubble did not permit them to accept another point of view (overwhelming belief in rule of law), or I would rather say it forced them to adapt to the information bubble preexisting from the moment they got acquainted to it, while due to their nature, NGO members would seemingly adhere to completely the opposite.

We have tried to break that bubble. We provided scarce but still existing Ukrainian court decisions that applied rule of law as a real concept and not as a nice and trendy idiom meaning nothing definite. We shared the experience of the other countries (mostly neighboring states that had similar problems in transition from socialistinfluenced societies). We have also equipped them with all the necessary legal means they require in their work (including international treaties and relevant acts of national legislation). It had an effect.

I would not say that the amount of responses with changed views increased significantly. We did not expect this, but the rise was to about $15^{-20} \%$. Fighting the post-truth that was playing with their minds for over 70 years is not an easy task. Most of them still adhere to the idea that law is a mere set of oppressive regulations, and rule of law (even if being applied literally) is nothing more than an experiment in idiots' hands who fear nothing. Not many sane people would want to be called idiots and be, in fact, idiots.

"People have families to feed." These were the most common words I have seen in their written responses after trainings. This also means that their post-truth reality was unfortunately not much changed by our trainings. This is not a rare case, however. To change someone's perception one needs to change his/her set of authorities. We could not influence city mayors who were (and still are) the primary authority for municipal officials and the compelling force for local NGOs as they need to interact with the mayor for different purposes regardless of what they think of him/her personally (while some of them get direct funding from municipal budget, which seriously affects their views and activities). One of the representatives (who has also preferred not to disclose his/her name) said, "In changing societies in order to combat post-truth you need a person or set of people who would do all the dirty work, get all the negative consequences, and maybe give their life for those changes." While there were some examples in history, those don't seem to be common in modern Ukraine (and not only Ukrainian society). These two experiments (the one with the students and the one with the municipalities) have brought me to certain conclusions. 
There is no universal mechanism to fight post-truth. Many researchers suggest their own set of instruments, mostly including fact-checking, conscience, and common sense. ${ }^{15}$ I agree with all this but add that the main instrument in fighting post-truth with negative consequences is the complexity of the means and instruments applied. Moreover, these means and instruments should be applied jointly by the members of the society who are engaged in post-truth fighting. That is when the concept of trust comes up. I strongly agree with F. Fukuyama that trust is one of the founding principles which determine the prosperity of every society. ${ }^{16}$ He expressed this view in many of his works I encountered. Prosperity in post-truth reality will most certainly include the ability of the members of society to distinguish truth from post-truth, to have access to the truth, to be able to challenge individual members' or collective view on what a truth is, and to forgive each other for any misconceptions. This aspect heavily relies on the concept of trust as well.

What frightens me the most is that, contrary to the famous perception that the younger people will bring the needed change, it seems that in most cases they choose to adapt to the existing circumstances instead of leading the change (at least in the Ukrainian case). It frightens me that this seems to be the case when post-truth has much more strength than the well-established means of combating it.

Legal interpretation is used as a tool in the formation of the students' perceptions as the abovementioned examples reveal. The same way it applies to the way adults perceive the reality, it applies to them (as the results of the second experiment reveal). I did not deeply analyze the answers of the students from Political Science stream, as these expressed mostly the ideas I expected to get from them. Unlike lawyers, political scientists are supposed to be able to build mechanisms of social functioning in each society. And I must admit that law is only one of the means they can use to achieve that goal. There are many other means they can use.

It may also be the age as these third-year students are not as young and full of fresh ideas as first-year students and not as experienced with having some of their ideas crashed already as fifth-year students. Nevertheless, I consider all these responses to be an example of post-truth. Moreover, it is post-truth that I and my colleagues are producing for them and with them at the university. I do not view my aim as a university instructor to reveal truth to the students. I am not a prophet or any other charismatic religious leader. My aim is to urge them to think for themselves and do everything they wish to discover the truth and to be able to do that. My other important aim is to help them in that uneasy process. I would call it an educational post-truth which provides its own information bubble of theories, ideas, and their combinations. In fact, I must admit that we, as educators, are no better and no worse post-truth producers than lawyers and journalists are. I think that in most cases our product could be called

15 Iryna Ladyka, "Pyat dumok pro postpravdu [Five Thoughts on Post-truth]," Studway (2017), accessed May 15, 2018, http://studway.com.ua/postpravda/.

16 Francis Fukuyama, Trust: The Social Virtue and the Creation of Prosperity (New York: Free Press Paperbacks, 1996). 
positive post-truth (which is quite unusual for this term nowadays) as its aim is to provide our students tools and equipment that will enable them to recognize real posttruth and fight it if needed.

\section{Post-truth, Legal Interpretation and Ukraine}

Now, let's turn to the last aspect this paper is devoted to. Post-truth is not purely associated with the Brexit campaign and the last presidential elections in the United States of America. Ukraine has also been in world news' mentions of "post-truth" for quite a while, and it still pops-up in the media occasionally.

The Ukrainian crisis of 2014 and its aftermath may definitely be regarded as a post-truth battle. This battle is not over yet, by the way. This clash of ideas, ideologies, and views is not unknown in the world, however, as I mentioned earlier in this paper, it was very hard for me and to many other people who surround me to expect that my country will end up in a war without a clear end (at least as I can elaborate for today).

The reasons for this conflict were already widely described in many different sources. ${ }^{17}$ I would only allow myself to state certain important points to provide a more comprehensive picture. It is quite hard to establish truth in the field of history, and very easy to end up in post-truth state, but I will still try.

There is a widely accepted view (which does not necessary mean that it is true) that Ukraine was formed from parts of the Kyivan Rus (an East European ancient state which existed around 9th-1oth centuries with the capital in Kyiv and located at its most prosperous times in significant parts of modern Ukraine, Belarus and some parts of European Russia). After numerous Mongol attacks, it dissolved into different pieces (self-governed states) that were later either conquered by neighboring states or eventually united to form parts of today's Russia. The parts that would become Ukraine were under the rule of Lithuania and Poland before they were conquered by the Russian Empire. Some parts of modern Ukraine were under the Ottoman rule for a significant period. During World War I, Ukraine enjoyed several years of independence until it was finally conquered by the Bolshevik Soviet Union and became part of it. Ukraine proclaimed its independence in 1991 and has been forming its new state since then.

The formation of the new state was not an easy task to do as almost 70 years of Soviet Union rule with a communist ideology impacted both the state of Ukrainian society and the state of Ukrainian law. Moreover, Soviet ideology also significantly influenced people's mindset and their traditions and ideals. That influence was so strong that there still is a significant portion of Ukrainian population which is being guided by them partly or fully. I may suppose that I am also still being guided by certain parts of that ideology myself.

17 See e. g. Alan Yuhas, "Ukraine Crisis: an Essential Guide to What Happened," The Guardian, April 13, 2014, accessed May 15, 2018, https://www.theguardian.com/world/2014/apr/11/ukrainerussia-crimea-sanctions-us-eu-guide-explainer. 
Nevertheless, the Ukrainian state was formed on democratic principles on August 24 , 1991. This decision was confirmed in a referendum on December 1, 1991. I must say, however, that most people did not even recognize much that one state ceased to exist, and they became the citizens of a new one. We adopted the new currency, intensified the use of Ukrainian language and started publishing new school textbooks. But all the societal processes stayed the same, more or less, as they were in Soviet times. It is economic situation that changed. Most people lost their jobs and were more concerned with surviving the sudden poverty than with thinking about communist or anti-communist ideals. This was a time of high corruption, and high levels of violence supported the ongoing privatization of state property process. Because many people suddenly became poor, many of them wanted to return to communist rule. Their communist post-truth was strong enough to surrender to the new realities. I have often questioned myself on the reasons for this.

I have always questioned myself about why people wished to restore the power that brought them so much trouble. My great-grandfather used to own a house with land in Central Ukraine before the 1920s and 1930s. His family was living from farming and had no significant problems at that time. The only problem they had was that they were not willing to be subject to collectivization. Nevertheless, the house and the land were seized from them. My great-grandfather was put in jail as a kulak and served his sentence there until the start of World War II, when he was put in military service and was killed somewhere around Vitebsk. We were not even informed where his grave was, and I still have not found it. My other great-grandfather, who also owned land in another village in Central Ukraine, did not resist the land seizures and thus was not imprisoned. But he disappeared during World War II. My parents and grandparents have told me our family was regularly visited by KGB agents who checked on whether he may have returned. Having nothing left, both families miraculously survived the Great Famine of 1932-1933 and managed to give birth to my grandparents. Having known all this, I have always questioned myself on the reasons why people would wish for those tragedies to repeat, and I think I found the answer.

People tend to remember the good moments of their lives. Some of them did not have to go through what my family had to go through. When I hear nostalgic regrets for Soviet times, these are usually expressed by people who lived in cities, not in villages. Many of those I encountered were either in the military, served in the police, or were the employees of military factories that quit or almost quit production after the collapse of Soviet Union. They were considered a privileged class at that time, and thus they have grounds for regrets. Their families had a much different experience than my family had. I have never heard any Soviet nostalgic ideas in my family throughout my whole life. Nevertheless, Soviet ideas being supplied by rich Soviet post-truth were present (and I must admit are still present) in my family to this day. We simply had no access to any other ideas.

Being populated mostly by former Soviet citizens, Ukraine has faced numerous acts of revenge by pro-Communist and pro-Russian forces. Most have exploited post- 
truth methods (as we can call them now). They were mostly appeals for Ukrainians and Russians to jointly form one nation. This idea co-existed with the concurring idea of Russians being regarded as the older brother and Ukrainians being the younger brother (as strange as these two ideas jointly may sound). Propagandists have also exploited the old Soviet idea of the so-called "Soviet nation" and "Soviet folk," the creation of which was the main idea of that nation and many other appeals to the past. Most of this could now be clearly called post-truth, as it mostly appealed to human emotions and was quite successful, especially with the elderly. There are many more examples of the kind.

Time passed, and the ideas of some parts of the population changed. Nevertheless, we still have different parts of the nation living in different information bubbles and thus multiple post-truth perceptions. This clash contributed significantly to Orange Revolution of 2004, and consequently to Euromaidan (or Revolution of Dignity) of 2014.

Post-truth, however, was not used for propaganda purposes only. There were clear cases of post-truth methods being used in modern Ukrainian legal system. One of the most significant examples of this approach is the decision of the Constitutional Court of Ukraine \#2O-rp/2010 it passed in 2010.18 I have already turned to its analysis in one of my previous works; however, I did not deal with it from a post-truth point of view.19

The facts preceding the case were the following. Ukraine had adopted its Constitution in 1996. This document replaced the old Constitution of Ukrainian Soviet Socialist Republic and established a presidential form of government with a strong and powerful President. The Orange Revolution in 2004-2005 ended in a compromise requiring the Constitution then in force to be amended to reduce the President's powers. Most of the former presidential powers would go to the Parliament. This compromise was a tough one. The decision was made in a revolutionary time with people on the streets, and our parliament did not bother much with following of the procedure for amending the Constitution. Certain important aspects (such as the obligatory consent of the Constitutional Court of Ukraine on the constitutionality of the proceedings were omitted due to lack of time, as these procedures are quite lengthy). The abovementioned decision of the Constitutional Court of Ukraine restored the old Constitution of 1996 on the grounds of procedural breach while inserting the amendments. This decision showed the dangers to which a post-truth legal environment may lead.

I will not deeply analyze this decision in all its legal terms as I have already done this. ${ }^{20}$ I wish to point out an interesting fact, however. The decision was passed when our former President Viktor Yanukovych had been in office for about 6 months. The election took place about 6 months before the decision was passed by the court. He was elected President according to the Constitution amended in 2005. This decision

The Decision of Constitutional Court of Ukraine No. 20-rp/2010, accessed December 16, 2018, http://zakon2.rada.gov.ua/laws/show/vo2op710-10.

19 Ievgen Zvieriev, "The Interpretation Power of Ukrainian Constitutional Court as One of the Main Reasons of Ukrainian Crisis of 2013-2014," Míl'niky Práva v Stredoeurópskom priestore (2014): 856-6o. 
provided him powers he was not initially elected with, and, from my point of view, this significantly contributed to the escalation we faced in 2014. I view this also clearly in the ideas of post-truth, although the link cannot easily be established.

Post-truth is differentiated from the pure manipulation by the necessity of having an emotional trigger. Even though it is not a clear consideration, as the court has based its decision purely on procedural grounds, we may be able to spot this emotional trigger if we dig a little deeper. I spotted this trigger in the very idea of justice. The court turned to this principle several times in this decision, and I claim that justice does deal with emotions. Justice is itself an emotional state of relief for an injured party. An injured person turns to the court just for that.

Ancient people (and quite a few modern ones) would often go for revenge. Revenge is a form of justice in many cultures. This appeals to the emotional state, and thus may qualify as post-truth methods. Moreover, by applying an emotional trigger, we may mean here the mere absence of emotions in the place where they should have been present, though after a careful analysis of this simple case in its context, I see signs of injustice instead of seeing signs of justice as the court did. It may simply not be just when voters' expectations and the mandate they provided the person they elected are being substituted by the casuistic decision of the constitutional court. This is clearly the breach of the Rule of Law principle (at least in the understanding of this principle I was taught by my professors and teach my students and different training participants currently).

Mostly due to the complexity and timing of the hearings and due to the inertia and general distrust in old Ukrainian court system, most of the population did not notice this significant change. They realized that much later when the President started turning to these new powers he acquired based on that decision. I think that the escalation of 2014 could have happened back in 2010 had most of Ukrainian population been aware of the decision and, most importantly, of the consequences it was about to bring.

This example is not the only one in the series of examples of how post-truth is being used by Ukrainian court system. General courts have often applied post-truth methods within different raiding schemes, when the control over certain enterprises was shifted from the legal owner to the raiders. ${ }^{21}$ Quite a few of them were very successful for the raiders.

Ukraine remains very vulnerable for post-truth as a country, and Ukrainians remain very vulnerable for post-truth influence as a people and as individuals. Not only has the number of people still admiring old Soviet order (as a substitute to the modern absence of order, in their view) not diminished significantly, it is also that due to many failures of the current government that many younger people are adopting these ideas. The clear examples of that are my older law students, as well as younger NGO leaders and younger municipal officials I have described before in this paper. Moreover, I am starting to hear more conversations among ordinary Ukrainian people who admire Stalin and his methods. I always question myself on what kind of post-

21 See e. g. "Reiderstvo v Ukraini — khto vynen? [Raiding in Ukraine — Who is Responsible?]," accessed May 15, 2018, http://kiev-chamber.org.ua/uk/134/995.html. 
truth may bring some people to dream about this nightmare, and I think I have found an answer to that as well. In most cases, the ones who admire such approaches do not wish those methods to be applied to them. They wish them to apply to someone else. I consider this to be a sign of the vulnerability of those individuals. This is a special form of revenge by those who may have had some kind of power in the past (of any kind and significance) and wish to get at least a moral pay-off currently. This is a clear evidence of post-truth influence.

\section{Conclusion}

Post-truth is mostly effective with vulnerable people, with the people who have doubts, and with the ones who are not able to clearly establish what a rightful truth paradigm is for them. Post-truth is very effective with the people who cannot compromise or question the correctness of their thoughts and logic. The effect doubles, if not triples, in societies of distrust.

My small experiments have shown me certain alarming notes. The fact that the students who studied law at one of the best universities in Ukraine for 5 years have changed their ideas almost completely to the opposite to what they were taught and would rather adhere to the reality in practice than to the ideas their professors shared with them while trying to influence that practice, if not changing it, is more than alarming. As for me, it shows that contrary to our expectations that the youth will bring changes, the results unfortunately show that they would rather adapt to the existing conditions. The same applies to the younger municipal officials I worked with. They should be the ones to bring change. However, they do the opposite instead (most of them). Instead of trying to establish new and modern practices, they mostly go with the flow and adapt to the existing conditions. And some NGO leaders and participants do the same. The amount of the ones going with the flow was lower than in the previous group but was still significant.

All this frightens me really because I've spotted a similar tendency throughout Eastern Europe (in several countries). This means that we should not forget that before the real war we always have a hybrid information war which applies post-truth as its major tool, and this tool is being utilized in most areas, law being one of the most important of those.

What are the ways we may address that important post-truth issue? I think that the most important contribution should come from education. This does not mean that education will eliminate all the possible cases when post-truth may apply all its negative features. There are many examples of well-educated people becoming victims of post-truth of a different kind. The strongest impact education can make is to teach people to think critically, to have wide expertise and experience, and to be tolerant of opposing views (while it does not necessary means that the person has to fully agree with them). Another important contribution education provides is the knowledge of facts. The person who is aware that $2+2=4$ may not be easily fooled and made sure that $2+2=5$, for example. Education provides truthful facts that are very hard to combat 
by post-truth methods. Thus, education has always been a treasure that provides or opens additional possibilities. That is why it is usually very expensive and should be used wisely. That is what my professors have taught me, and that is what I try to teach my students.

However, education alone may not always fully help to combat post-truth. As I have frequently stated, I completely agree with F. Fukuyama's concept of trust and with his idea that trust is the means to prosperity for every society. This means that members of the society need to trust each other in issues they are not fully competent in and support each other. This trust and support will in most cases leave no room for post-truth influence except if this post-truth applies its methods to all the members.

Another important mean to combat post-truth is each person's self-realization. Each person needs to be a well-developed, sustainable individual confident in his/her own self, while open to possible changes and critical of the possible ways to harm that state, post-truth being one of them. That requires constant hard work, flexibility, good time-management, as well as many other features we develop throughout our lives.

And the most important mean to combat post-truth is the simple desire to do that. While working with my students I try to foster their desire to learn something new, to address pre-existing problems in a new and critical way, to experiment, and to not be afraid to fail in something as one of my U. S. high school teachers have said back when I was on exchange in 2000: "It is better to study from the teachers than from the life, because unlike other teachers life would first give an exam, and only then teach something." This desire to combat post-truth should in fact be the initial step of this uneasy process. There are many cases in this world when it is not taken, with the most common reason being simple human laziness. While that feature has been the reason for many important inventions, it is much more known for its negative impact on human lives and occurs more often than the discoveries of world significance.

As I mentioned above, law has always been exposed to post-truth. It brought both positive and negative impacts from its application in legal cases. Nevertheless, a welltrained lawyer should be equipped with the means for enabling him/her to be able to spot post-truth and/or to use it for the benefit of his/her client. It should always be noted, though, that post-truth is a very powerful tool that should be dealt with very carefully.

All the ideas about post-truth in law and generally were applied and still are applied in my country. The state Ukraine is in right now is in many ways the result of post-truth methods used by different actors in different settings, at different times, and for different purposes. The Ukrainian example should provide a strong caution for other nations facing similar issues as well as to the rest of them that may face them in future because no one may ever be sure in this world what exactly happens tomorrow. Chances are post-truth may end up doing harm somewhere else. 


\section{Bibliography}

Fukuyama, Francis. Trust: The Social Virtue and the Creation of Prosperity. New York: Free Press Paperbacks, 1996.

Konev, Egor. "Zhurnalistskie printsipy v epohu postpravdy [Journalist Principles in Posttruth era]." Mezhdunarodnaya zhurnalistika 2018. Globalnye vyzovy, regionalnoe partnerstvo i media. Materialy VII Mezhdunarodnoy nauchno-prakticheskoy konferencii. (Minsk, 2018): 137-42.

Koziubra, Mykola. Zahalna teoriya prava [General Theory of Law]. Kyiv: Vaite, 2015.

Ladyka, Iryna. "Pyat dumok pro postpravdu [Five Thoughts about Post-truth]." Studway. Accessed May 15, 2018. http://studway.com.ua/postpravda/.

Maclean, Ian. Interpretation and Meaning in the Renaissance: The Case of Law. Cambridge: Cambridge University Press, 1992.

Marmor, Andrei. "Truth in Law." Accessed June 21, 2018 http://law.bepress.com/usclwpslss/art73/.

Moore, Michael S. "Interpreting Interpretation." In Law and Interpretation. Essays in Legal Philosophy, edited by Andrei Marmor, 1-30. Oxford: Clarendon Press, 1995.

Nersesyanc, Vladik S. Obshchaya teoriia prava i gosudarstva [General Theory of Law and State]. Moscow: Norma, 2002.

"Reiderstvo v Ukraini — khto vynen? [Raiding in Ukraine-Who is Responsible?]." Accessed May 15, 2018. http://kiev-chamber.org.ua/uk/134/995.html.

Schiller, Arthur A, "Roman Interpretatio and Anglo-American Interpretation and Construction." Virginia Law Review 27.6 (1941): 733-68.

Shugrina, Elena S. Tekhnika yuridicheskogo pisma [Technique of Legal Drafting]. Moscow: Delo, 2000.

Yuhas, Alan. "Ukraine Crisis: an Essential Guide to What Happened." The Guardian, April 13, 2014. Accessed May 15, 2018. https://www.theguardian.com/world/2014/ apr/11/ukraine-russia-crimea-sanctions-us-eu-guide-explainer.

Zvieriev, Ievgen, "The Interpretation Power of Ukrainian Constitutional Court as One of the Main Reasons of Ukrainian Crisis of 2013-2014." Míl'niky Práva v Stredoeurópskom priestore (2014): 856-6o.

\section{(2)}

Ievgen Zvieriev is a Senior Lecturer at the Faculty of Law, National University of Kyiv-Mohyla Academy. He received his PhD from National University of Kyiv-Mohyla Academy and LLM from Central European University. His research interests include legal interpretation, post-truth, legal philosophy. Dr. Zvieriev was awarded an "Instructor of the 2018 Year" by National University of Kyiv-Mohyla Academy Faculty of Law in June, 2018. 